\title{
NEGARA DAN BANGSA
}

Oleh Shohibul Anshor Siregar

Semua ancaman yang pernah terjadi akan terus menjadi ancaman selama keadilan tidak dihadirkan, tak perduli permainan doktrin terus dilakukan untuk menjejalkan bahwa bangsa adalah suatu jiwa atau suatu azas spiritual.

Secara teoritis terdapat banyak argumen sejarah, politik, ekonomi dan budaya yang menunjukkan bahwa sesungguhnya tidaklah mudah untuk menemukan kesepakatan yang memuaskan semua pihak tentang Presiden seperti apa yang paling baik untuk Indonesia khususnya saat ini.

Hal itu jelas tidak selalu terjawab oleh ide demokrasi beserta prosedur yang dijalankan untuk melegalisasi keterpilihan seseorang untuk menjalankan tugas sebagai presiden setiap 5 tahun. Karena itu pertanyaan yang harus dijawab adalah tingkat kepuasan seperti apa yang memenuhi kriteria untuk beroleh kualitas pengakuan paling tinggi untuk kepresidenan seseorang. Terus terang ini tak akan pernah menjadi urusan para penggantang kekuasaan di dalam maupun di luar partai.

Disadari bahwa elemen dan subjek masalah penyumbang pertikaian pendapat selain tak begitu mudah dikenali, juga sulit diurai, diukur dan diperbandingkan pada skala-skala tertentu. Tetapi tidaklah dengan begitu assesment tak bisa dilakukan. Diskursus serupa ini tidaklah hal baru sama sekali di Indonesia. Lagi pula hampir semua negara di dunia mengalaminya dan tentu dapat memetik pelajaran terbaik dari setiap kasus, meski pun sejarah khas suatu negara-bangsa tetap menjadi determinan utama.

Untuk Indonesia misalnya, pertikaian pemikiran ideologis yang kerap bersifat diametral sekaligus antagonistik kerap menandai ketegangan dialog yang tak pernah usai antara kalangan berbasis pemikiran keagamaan dan kalangan berbasis pemikiran kebangsaan di negeri yang secara faktual berkomposisi demografis mayoritas muslim ini. Ingatlah bahwa sebetulnya di dalam setiap upaya pemilahan seperti ini (agama dan kebangsaan) sebuah kekeliruan yang akhirnya merendahkan bagi kalangan pertama telah berulangkali erjadi, karena ada penekakan dalam anggapan bahwa kalangan pertama tak begitu mengindahkan kebangsaan. Padahal sejarah membuktikan sebaliknya.

Memang kecenderungan melemahkan pemikiran keagamaan dari waktu ke waktu dalam relasi yang tak pernah adil, telah menjadi bukti menguatnya sekularisasi dan secara terus-menerus negara telah diposisikan dalam karakter kebangsaan seperti itu.

Urgensi penyelesaian konflik berkepanjangan antara apa yang selalu dengan salah dipilahkan sebagai agama dan bangsa dalam sebuah relasi yang konfliktif dalam politik Indonesia secara sederhana selalu difahamkan orang sebagai agenda pluralitas yang belum matang dan bahkan buktibukti intoleransi yang berbahaya. Lebih celaka lagi selalu dikaitkan dengan ancaman bersifat global hanya dengan menunjukkan adanya ISIS, Alqaeda dan gerakan-gerakan reaktif-artifiasial lainnya tanpa kemasuk-akalan yang lazim oleh cara berfikir yang lurus. Ini tidak bermaksud membantah sama sekali atas fakta-fakta yang dapat dikonfrontasikan seperti simptoma-simtoma disharmoni yang kerap muncul dalam kehidupan sehari-hari. Justru di sini diperlukan sekali kejujuran sembari menjauhkan prasangka tak berdasar. 
Dalam catatan pembentukan Indonesia pertikaian pemikiran yang terjadi saat perumusan dasar negara dan undang-undang dasar negara harus difahami bukan sesuatu yang mendadak-sontak hadir saat forum dibuka pasca pembentukan Badan Penyelidik Usaha Persiapan Kemerdekaan Indonesia (BPUPKI) oleh Jepang yang kemudian beralih nama menjadi Panitia Persiapan Kemerdekaan Indonesia (PPKI).

Perbenturan pemikiran di dalam BPUPKI sebenarnya sudah dilalui dengan begitu mulus, dan hasilnya Islam secara legowo diterima sebagai nilai-nilai dominan untuk fundasi Indonesia berdiri dan merdeka. Kendati demikian, dan meski pun dalam salah satu dari lima sila (sila pertama) dasar negara disepakati dan yang kemudian dinamai Pancasila termaktub bunyi "Ketuhanan dengan kewajiban menjalankan syariat Islam bagi pemeluk-pemeluknya, itu tak berarti mayoritas Islam memenanginya dengan cara non-musyawarah. Semua dilalui dengan diskusi sehat, pertukaran pikiran dan gagasan, pengkonfrontasian argumen dan data.

Namun di luar forum resmi berlangsung negosiasi. Ada desakan yang misterius untuk merubah kesepakatan hingga bunyi sila pertama menjadi Ketuhanan Yang Maha Esa. Kata-kata lain dalam kalimat utuh sebelumnya dihapus.

Belakangan ada yang tak puas dan melakukan usaha untuk mengembalikan. Gerakan-gerakan separatis yang terjadi tak lama setelah kemerdekaan tak hanya muncul dari kalangan berkonotasi perjuangan ideologi Islam, malah didahului oleh pemberontakan PKI di Madiun pada tahun 1948 yang terkait dengan jatuhnya kabinet Amir Syarifuddin dengan keterkaitan dengan kegagalannya dalam Perundingan Renville yang sangat merugikan Indonesia.

Pemberontakan Darul Islam (DI) dan Tentara Islam Indonesia (TII) pada tahun 1949 di bawah pimpinan Sekarmadji Maridjan Kartosoewiryo, Pemberontakan Pemerintahan Revolusioner Republik Indonesia (PRRI) dengan pentolan Dewan Banteng (Sumatra Barat) yang dipimpin oleh Letkol Ahmad Husein; Dewan Gajah (Sumatra Utara) yang dipimpin oleh Kolonel Maludin Simbolon; Dewan Garuda (Sumatra Selatan) yang dipimpin oleh Letkol Barlian; dan Dewan Manguni (Sulawesi Utara) yang dipimpin oleh Kolonel Ventje Sumual, yang kemudian meluas ke Indonesia bagian Timur antara lain dengan pernyataan Somba memutuskan hubungan dengan pemerintah pusat (Februari 1958).

Gerakan Aceh Merdeka (GAM) menuntut Nanggroe Aceh Darussalam lepas dari Negara Kesatuan Republik Indonesia yang melahirkan sejumlah konflik sejak tahun 1976 yang dipimpin oleh Hasan di Tiro. Dalam kaitan dengan ancaman keutuhan negara-bangsa, tragedi Nasional G 30 S/PKI Tahun 1965 dengan gerakan Nasionalisme, Komunisme dan Agama (Nasakom) yang secara faktual adalah menjadi salah satu kekuatan penting pada masa Demokrasi Terpimpin, berakhir dengan penumpasan berdarah.

Sejumlah pemberontakan lain seperti APRA (Angkatan Perang Ratu Adil), gerakan Andi Azis dan juga Republik Maluku Selatan (RMS), yang terjadi pada masa pemerintahan RIS tak kurang menguras energi nasional. Republik Maluku Selatan (RMS) diproklamasikan pada 25 April 1950, memisahkan diri dari Negara Indonesia Timur. Gerakan ini banyak didukung bekas prajurit KNIL dan orang yang pro-Belanda lainnya. Di antaranya Dr. Chr.R.S. Soumokil, bekas jaksa agung Negara Indonesia Timur yang kemudian ditunjuk sebagai Presiden. Di Belanda RMS malah mendirikan pemerintahan di pengasingan. 
Semasa pemerintahan SBY (2007) ada beberapa pemuda Maluku mengibarkan bendera RMS pada saat perayaan hari keluarga nasional di Ambon. Malah pada tanggal 24 April 2008 Perdana Menteri pemerintahan RMS di pengasingan (Belanda) John Watilette mengemukakan propaganda untuk memperkuat antipati terhadap Indonesia.

Organisasi Papua Merdeka (OPM) yang didirikan tahun 1965 dikenal dalam diploasi internasional sebagai sebuah gerakan yang bertujuan memerdekakan Papua bagian Barat. Alasan historis dan antropologis yang selalu mengemuka adalah bahwa OPM merasa mereka tidak memiliki hubungan sejarah dengan bagian Indonesia yang mana pun. Pasalnya penyatuan ke dalam NKRI sejak tahun 1969 ternyata lebih dirasakan sebagai kesepakatan antara Belanda dengan Indonesia sekadar menyerahkan wilayah yang selama ini dikuasainya kepada bekas jajahannya yang berubah status menjadi merdeka. OPM tetap menilai perjanjian itu sebagai serah-terima di antara sesama penjajah.

Kapankah semua ini akan berakhir? Berdasarkan kajian sejarah dan motivasi untuk setiap gerakan separatisme seperti itu, biasanya orang menilai basis kebangsaan atau kekuatan keagamaan atau bahkan kombinasi keduanya yang dihubungkan dengan perasaan tak memadainya kekuatan politis dan ekonomi yang melahirkan perasaan ketidak-puasan (relative deprivation) adalah faktor penyebab utama.

Jika menilik pada kejadian-kejadian yang acap di seluruh dunia, dalam hal ini Indonesia kiranya tidaklah bernasib yang begitu berbeda. Mari dipetik beberapa contoh. Misalnya Afrika Selatan yang bertikai dengan daerah Zulu; Amerika Serikat dengan Alaska;,Hawaii dan Puerto Riko; Angola dengan Cabinda, Belgia dengan Flandria, Walonia; Bosnia-Herzegovina dengan bangsa Serbia, Kroasia dan Bosnia; Britania Raya dengan Irlandia Utara (IRA, Sinn Féin, Partai Buruh dan Sosial Demokratik, Skotlandia, Wales, dan Cornwall.

Di Cina urusan dengan Taiwan, Mongolia Dalam, Tibet, Xinjiang (Gerakan Muslim Turkestan Timur) juga termasuk seagai gejolak besar, sebagaimana halnya Filipina yang berurusan dengan separatis Muslim Moro di bagian Selatan; India dengan Kashmir, Sikh, Bodoland, Assam dan Nagaland; Irak dengan Kurdi dan Syi'ah; Iran dengan Kurdi, Arab dan Azeri; Italia dengan Padania (Lega Nord), Tyrol Selatan, Sisilia; Jerman dengan Bavaria, Separatisme Alemannik.

Kanada dengan Quebec, Kanada bagian Barat; Republik Demokratik Kongo dengan daerah Katanga; Nigeria, Maroko dengan front Polisario di Sahara Barat; Myanmar dengan suku Karen dan Kachin; Pakistan dengan Kashmir; Perancis dengan Corsica, Brittany, dan Savoy; Rusia dengan Chechnya dan Serbia (Kosovo); Senegal dengan Casamance; Somalia dengan Somaliland; Spanyol dengan Basque, Catalonia dan Galicia; Sri Lanka dengan Macan Tamil; Sudan dengan daerah selatan yang penduduknya kebanyakan pemeluk animisme dan Kristen; Suriah dengan suku Kurdi; Thailand dengan komunitas Pattani; Turki dengan suku kurdi Kurdi, dan lain-lain.

Sebagaimana halnya negara-negara lain yang secara bersama terus berkembang dalam tatanan globalisasi, pertanyaan bersama negara-negara di dunia saat ini ialah perlukah sebuah upaya redefinisi dan revitalisasi konsep kebangsaan untuk Indonesia agar bentuk paling baik bagi masa depan dapat semakin terjamin?

Semua ahli sepakat bahwa sebagai konsep sosial, nasionalisme tidak muncul dengan begitu saja tanpa proses evolusi makna melalui media bahasa sebagaimana dikemukakan dalam studi semantik 
Guido Zernatto (1944). Tetapi di atas segalanya penataan negara berbasis keadilan tetap sangat mengemuka, dan ini terutama menyangkut sejarah, budaya, ekonomi dan hukum.

Semua ancaman yang pernah terjadi akan terus menjadi ancaman selama keadilan tidak dihadirkan, tak perduli permainan doktrin terus dilakukan untuk menjejalkan bahwa bangsa adalah suatu jiwa atau suatu azas spiritual. Berhubung semua ini adalah kesatuan solidaritas yang besar dan bahkan perasaan pengorbanan yang terjadi pada masa lampau, dan yang terus dicita-citakan untuk masa depan, maka kesepakatan, keinginan yang dikemukakan dengan nyata untuk terus hidup bersama memerlukan resep baru besendikan keadilan.

Ketika orang di Indonesia selalu bergairah mengatakan bahwa suatu bangsa tidak tergantung pada kesamaan asal ras, suku bangsa, agama, bahasa, geografis, atau hal-hal lain yang sejenis, reifikasi telah sengaja dilakukan. Ini tidak membantah bahwa kehadiran suatu bangsa adalah suatu kesepakatan bersama yang diandaikan terjadi setiap hari antara manusia-manusia yang bersamasama mewujudkan nasion yang bersangkutan (Bachtiar, 2001: 33).

Tetapi konflik tidak selalu akan sulit dihindarkan dan akan bersumber terutama dari dua sumber utama, yakni perbedaan yang timbul antara kelompok etnis yang termasuk dalam negara-negara yang sebagian besar diperlakukan sewenang-wenang sebagai warisan dari periode kolonial, dan kesenjangan yang lebar antara elit kecil yang makmur dan sejumlah besar orang yang hidup dalam kondisi kemiskinan (Guibernau, 1996: 150).

Urusan keadilan bukanlah urusan pembahasaan belaka, melainkan bagaimana cara mengukur dengan takaran yang manusiawi tentang kemustahakan para pihak yang secara struktural memang harus diatur berdasarkan ideologi dan konstitusi negara. Itulah tugas kepresidenan Indonesia saat ini.

Shohibul Anshor Siregar

Naskah ini pertamakali diterbitkan oleh Harian WASPADA, Medan, 6 Agustus 2018, hlm B7 